\title{
Tree root development: the role of models in understanding the consequences of arbuscular endomycorrhizal infection
}

\author{
D Atkinson \\ The School of Agriculture, Department of Land Resources, 581 King Street, Aberdeen, AB9 1UD, UK
}

(COST Meeting, 21-23 May 1992, Dijon, France)

\begin{abstract}
Summary - The development of any root system is ultimately a function of the amount of carbon moved into the root system, the growth rate of individual root members, the rate of initiation of branch roots by existing roots and of root survival. All these parameters may be influenced by infection by AM (arbuscular mycorrhizas) with the magnitude varying between different fungi. If the morphological effects of $A M$ are to be understood well enough to allow their use as biological growth regulators then the integrated effects of changes in these separate root functions must be understood. This can be aided by the use of models. The use of the widely available package "STELLA" and the developmental model "Rootmap" to assess the results of changes in root survival and branching are discussed here.
\end{abstract}

root / AM / STELLA / rootmap / branching

\begin{abstract}
Résumé - Le développement des racines d'arbres : rôle des modèles dans la compréhension des conséquences d'une infection par les mycorhizes arbusculaires vasculaires. Le développement de tout système racinaire est en définitive fonction de la quantité de glucides qui y sont transportés, de la vitesse de croissance des racines individuelles, du taux d'initiation de racines latérales par les racines existantes et du taux de survie des racines. Tous ces paramètres peuvent être influencés par l'infection par les mycorhizes arbusculaires vasculaires (AM) avec une intensité qui varie selon les champignons impliqués. Pour comprendre les effets morphologiques de l'AM suffisamment bien pour pouvoir les utiliser comme régulateurs biologiques, il faut d'abord comprendre les effets intégrés de variations de ces fonctions élémentaires des racines. Cela peut être facilité par l'utilisation de modèles. L'utilisation du logiciel STELLA et du modèle de développement Rootmap pour évaluer les résultats de variations de la survie et de la ramification des racines est ici discutée.
\end{abstract}

racine / endomycorhize arbusculaire / modèle de développement racinaire / STELLA

\section{INTRODUCTION}

The development of the root system of a tree is a complex process in which development at any point in time is influenced both by the current provision of assimilates and the previous development of the root system. Both the provision of assimilates and their partitioning within the root system can be influenced by a range of external factors. Recently Berta et al (1990) and Hooker et al (1992) have shown that infection with AM can modify the development of the root system and that some of the effects of AM are likely to be due to changes in root system development rather than to direct effects of the fungus in improving nutrient capture. An understanding of the likely effects of $A M$ on root system development requires knowledge of the sequence of processes which control the form of the whole root system and knowledge of the influence of $A M$ on these individual processes. As individual AM fungi seem able to influence the different developmental processes to a different extent (Hooker et al, 1992) then a predictive understanding of the long-term implications of a given level of infection by a given fungal species will require an integrative approach. This can best be provided by the use of models. This paper examines the use of a commercial modelling framework package, STELLA (Anonymous, 1990) and a root development modelling programme, Rootmap (Diggle, 1989). The use of these methods to assess the effects of general developmental changes and changes in root branching respectively is illustrated in this study. 


\section{A DESCRIPTION OF ROOT SYSTEMS FORM}

A description of the form of a plant root system - its morphology - requires the specification of a range of different types of morphological parameters. Of these the most important are probably the following:

- structural morphology, ie the number of orders of branches, the number of higher order branches borne by a lower order branch root, the uniformity of branch production, etc;

- spatial morphology, the spatial distribution of root material within the soil volume. While the amount of root and its structural morphology will set the absolute limits for spatial distribution, there will normally be a range of options for the manner in which the same amounts of the same structural arrangement can be distributed through the soil volume. The angle of branching will have a major effect upon spatial morphology;

- quantitative morphology, the length and mass of the total root system and of its various components;

- temporal morphology, ie the ways in which morphology changes with time. Many roots have a brief longevity, and so the morphology of the root system may change greatly over a relatively brief period. This will apply less to systems with a high proportion of the length given over to woody permanent members. These aspects need to be assessed against a developmental model as a framework for assessing effects of AM.

\section{THE DEVELOPMENT OF THE TREE ROOT SYSTEM}

The developmental options for individual roots are shown in figure 1. Lower root orders may ultimately become woody roots or may die and rapidly decompose. Higher root orders, usually fourth order laterals and above, normally die after a limited period. Even within the lower orders of laterals it seems likely that the lower the root order the greater its probability of survival as a woody root, ie one where following the loss of the primary cortex the root produces wood cells and bark. These roots are able to give rise to branch roots and may live for many years.

In a tree root system grown in sterilised soil and thus probably non-mycorrhizal, $\approx 20-25 \%$ of the length of a root system dominated by primary

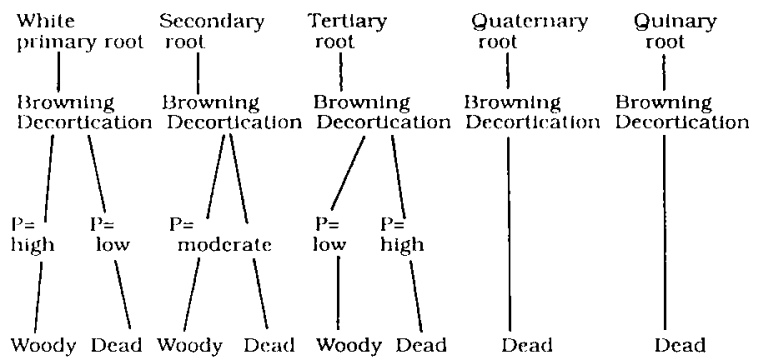

Fig 1. The fate of tree roots of different root orders. $P$ is the probability of an event.

and secondary roots survived into the second year of growth (Atkinson, 1985). Studies by Hooker et al (1992) have shown that in Populus $\mathrm{sp}$ infection with AM greatly increases the percentage of the root system present as higher order roots. Here the percent of tertiary and higher order roots increased from 41 to $77 \%$ in plants infected by Glomus caledonium. Using the simulation modelling system STELLA, a model has been developed to allow assessment of changes in the proportion of root surviving as woody roots on the cumulative amounts of different root types over a single season. The form of the model is shown in figure 2 and outputs for root systems with an overall partition of root length between brown, woody and dead root of 20:10:70 and $7: 13: 80$ is shown in figures $3 a, b$. On the basis of the results outlined above, the former with a high proportion surviving but only one-third becoming woody seems likely to be typical of a control (uninfected) root system while the latter with a lower fraction surviving but two-thirds becoming woody may be more typical of an AM-infected system.

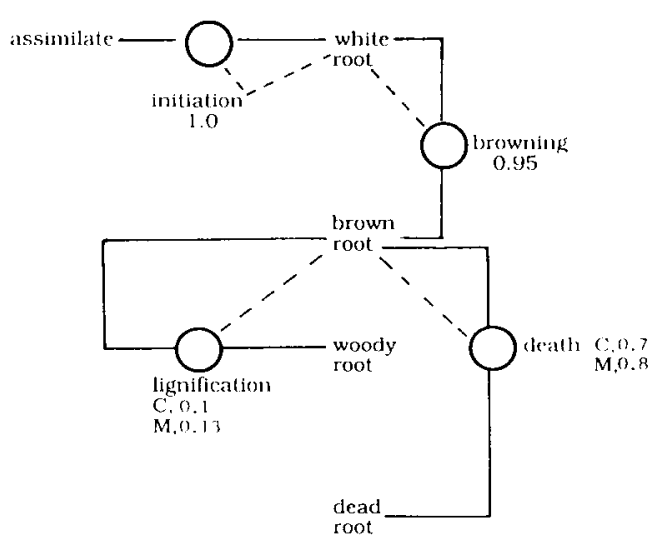

Fig 2. A STELLA model of the partitioning of resources between the different root states given in figure 1. The probabilities used in model runs to represent control (c) and mycorrhi$\mathrm{zal}(\mathrm{m})$ systems are indicated. Solid lines show the flow of assimilate, dotted lines feedback on processes indicated by 0 . 

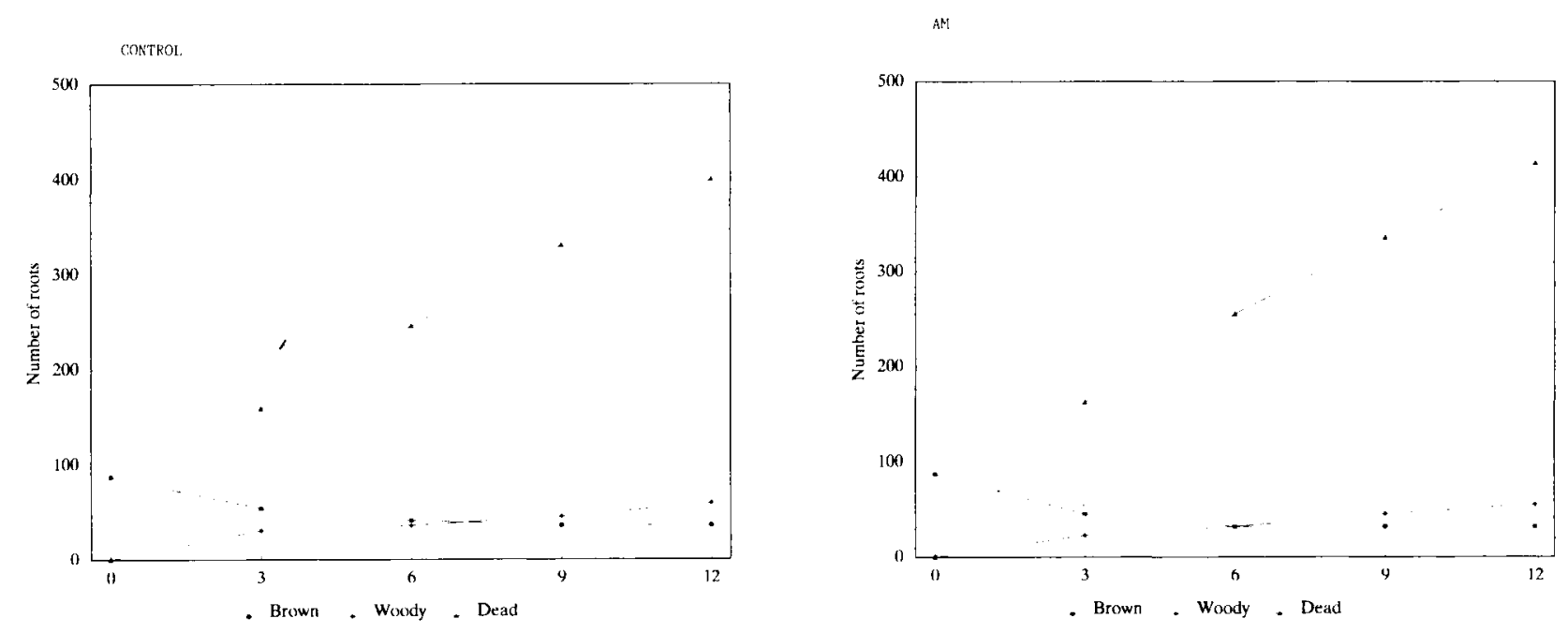

Fig 3. The effect of variation in the partitioning of assimilate into brown woody and dead root on the cumulative amounts of brown woody and dead root over a season. (a) output for probabilities of 20.10:70; (b) output for probabilities of 7:13:80.

Although in this case AM infection appears to result in a slightly reduced proportion of the system surviving as brown or woody root, more of the lower proportion surviving seems likely to become woody, and Knight (1992) has shown that mycorrhizal infection appears to increase the development of woody tissues in those roots which become woody. As a reduced number of thick woody roots is likely to lead to improved anchorage compared to a greater number of thin woody roots, this effect may be of advantage.

\section{EFFECTS OF BRANCHING ON ROOT SYSTEM FORM}

The rootmap model (Diggle, 1988) allows the effects of variation in the rate of growth of different members of a root system and the distance between different root orders to be assessed. Using the data of Hooker et al who assessed the effect of infection of a Poplus root system with $G$ caledonium on structural and quantitative morphology, the model was run to indicate the integrated effects of the changes measured on the morphology of an individual primary lateral root and its high order laterals. To use the rootmap model which was developed for cereals, the primary tree root was assumed to be similar to the primary seminal axis of a cereal plant. As Hooker et al only measured the final length of the roots of different orders rather than their growth rates, it has been assumed that root growth rates vary in the same proportions as final root length. The base rate of growth is taken as being that for the default value of the model, $2 \mathrm{~cm} \mathrm{~d}^{-1}$. The variable values used are as shown in table I and the forms of root systems generated in figures $4 a, b$. The root system infected by $G$ caledonium is shown as having fewer longer major branches each of which bear many more high order roots. This reflects the situation seen under experimental conditions.

\section{THE USE OF MODELS TO ASSESS MORPHOLOGICAL EFFECTS OF VAM}

The 2 models whose use has been illustrated here allow some but not all of the types of mor-

Table I. The parameters used in the rootmap model for control and AM-infected Populus trees.

\begin{tabular}{llllll}
\hline Root order & \multicolumn{1}{c}{$\begin{array}{c}\text { Growth rate } \\
\left(\mathrm{mm} \mathrm{d}^{-1}\right)\end{array}$} & & \multicolumn{2}{c}{$\begin{array}{c}\text { Branching interval } \\
(\mathrm{cm})\end{array}$} \\
\cline { 2 - 3 } \cline { 5 - 6 } & Control & VAM & & Control & VAM \\
& & & & & \\
\hline Primary & 20 & 19 & & 3.0 & 10 \\
Secondary & 4 & 8 & & 1.0 & 0.2 \\
Tertiary & 0.4 & 0.9 & & 3.3 & 1.0 \\
Quaternary & 0.4 & 0.3 & & 50 & 1.5 \\
Quinary & 0.01 & 0.1 & & 50 & 10 \\
\hline
\end{tabular}



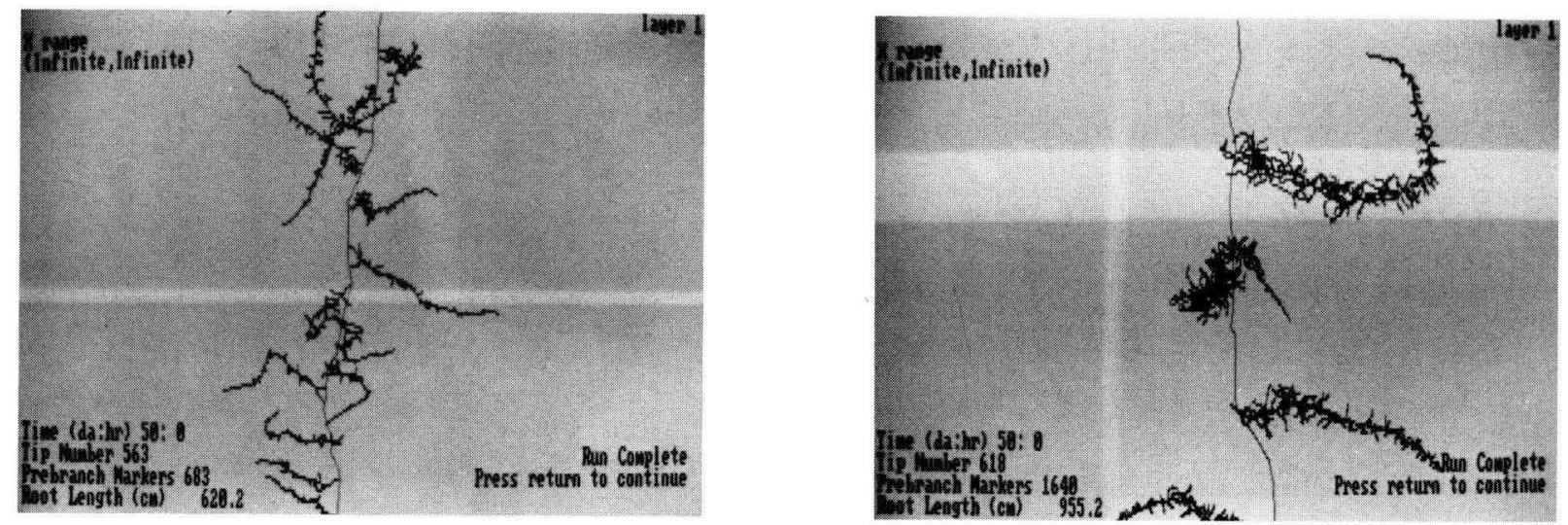

Fig 4. Visual representations of the primary lateral root and its subtended laterals of Poplus as indicated by the rootmap programme. (a) control uninfected; (b) infected with $G$ caledonium.

phological change to be assessed. The final form of the root system depends upon the 4 aspects of morphology described earlier. The data available from the studies described here and in the published literature do not allow effects on either spatial or temporal morphology to be estimated. The sub-model developed using the STELLA model allows quantitative morphology to be assessed while the rootmap model allows structural morphological effects to be visualised. There is a need to further develop the quantitative model to allow for the lignification of different root orders and the relative development of woody tissues in surviving woody roots to be quantified. A full understanding of development clearly needs a model which includes the 4 aspects of morphology and thus combines partitioning (eg STELLA) and spatial (eg rootmap) type models.

\section{REFERENCES}

Anonymous (1990) Stella. High Performance Systems. Hannover, USA

Atkinson D (1985) Spatial and temporal aspects of root distribution as indicated by the use of a root observation laboratory. In: Ecological Interactions in Soil (Fitter AH, Atkinson D, Read DJ, Usher MB, eds) Blackwell, Oxford, 43-66

Berta G, Fusconi A, Trotta A and Scannerini S (1990) Morphogenetic modifications induced by the mycorrhizal fungus Glomus strain E3 in the root system of Allium porrum L. New Phytol 114, 207-215

Diggle AJ (1988) Rootmap. A model in three dimensional co-ordinates of the growth and structure of fibrous root systems. Plant Soil 105, 169-178

Hooker JE, Munro M and Atkinson D (1992) Vesiculararbuscular mycorrhizal fungi induced alteration in poplar root system morphology. Plant Soil 145, 207214

Knight EA (1992) Variation in the root system of Betula pendula Roth. PhD Thesis, University of Aberdeen, UK 